\title{
Concentration of Authority and Rent Seeking Behaviour in Bureaucracy: An Evidence of Ineffective Governance in Bangladesh
}

\author{
Sayada Jannatun Naim, Abu Hena Reza Hasan \\ BRAC University, Dhaka, Bangladesh \\ University of Dhaka, Dhaka, Bangladesh \\ jannatun.naim@bracu.ac.bd, abuhasan@du.ac.bd
}

\begin{abstract}
Political leadership and public administration run the government of Bangladesh. Political wing is short tenured under a democratic system, but the public administration is permanent. An administrative process in Bangladesh made bureaucracy most powerful in the country. It has accountability to none but has controlling authority on all components of state including political leadership. This absolute power gives unlimited opportunity to administrative bureaucracy and other parts of the public administration of the country for exercising rent seeking behaviour. This paper evaluates the experience of common people of the country who used to interact with public administration for receiving public services using primary data collected through a field survey. The level of rent seeking is very high in public administration. The four major types of rent seeking behaviour among public officials are bribe, nepotism, and favouritism, use of official power to mischief common people and negligence to official duties and responsibilities. People used to suffer from rent seeking behaviour uniformly irrespective of their level of income and educational status. The root of rent seeking is the administrative bureaucracy. People face financial loss, delays in getting services from officials. It is necessary to reduce absolute power of public bureaucracy to control rent seeking of public administration.
\end{abstract}

Keywords: Bureaucracy; Rent Seeking; Political Leadership; Governance; Corruption; Government officials

\section{Introduction}

The government of a country is the joint responsibility of political leadership and public bureaucracy. Political leaders provide policy directions regarding public services and projects for the citizens of the country. The public bureaucracy is responsible for delivery, management, and implementation of public services and projects. In a democracy, political leaders come in power for a limited time, but bureaucrats hold offices for a long time in most of the democratic countries. Due to the short tenure of political leadership, public welfare in a democratic country is dependent on the quality of public bureaucracy. The friendliness, honesty, and sincerity of bureaucrats to the general people of the country are essential for satisfactory delivery of public services directed by the politicians. People unfriendly and corrupt bureaucrats are unable to deliver welfare to citizens of a country and may be the root of the failure of political governments. Bureaucrats when maximise their own benefits, ignoring their duties to common people, they are involved in corruptions. The bureaucracy in Bangladesh has lost its capacity to deal with the duties because of involvement in the political process, reluctance to engage regularly with civil society and media, and decline in educational quality and professional standards(Rashid, 2014).The colonial structure and working pattern of bureaucracy still exist in Bangladesh and the bureaucrats impeded reform efforts after independence of the country from Pakistan through politicisation of the administration and governance, resulting in a dominating bureaucratic structure with corruption (Mollah, 2011). Elected representatives of the people give direction or formulate policy on total national advancement, but the inefficiency of civil servants is barrier of doing the job of good governance in Bangladesh and it's time to re-evaluate and recast the entire system of civil services (Alam, 2011). The citizens of the country are disappointed with the performance quality of the bureaucracy of Bangladesh for the services they get from them and the issues of corruption, nepotism, inefficiency, lack of accountability and transparency among the members of the bureaucracy(Ferdous, 2016). The bureaucrats used to keep them busy to continuing good linkage with ruling political party to gain special favours and benefits that results in poor governance in the country and suffering for common people in Bangladesh (Doullah, 2016).

The UNESCO has defined governance as the norms, values and rules of the game through which public affairs are managed in a manner that is transparent, participatory, inclusive and responsive(UNESCO, 2018). Bureaucrats are primarily responsible for ensuring good governance in a country. The studies by researchers 
observed inefficient and ineffective bureaucracy in Bangladesh what is unable to satisfy the citizens because of the poor quality of performance. The concentration of power among bureaucrats by gaining favour of political leaders and their intention to maximise self-benefits made the governance in Bangladesh ineffective. Therefore, it's time to evaluate the entire system of civil bureaucracy. Hence, the objective of this paper is to discuss the character of public bureaucracy in Bangladesh and perception of citizens of country about public bureaucrats. This paper explores the characteristics of rent seeking and unfriendly behaviour of public administration. Using data collected through a field survey, it examines the characteristics and impacts of rent seeking on the life of the citizens.

\section{Literature Review}

Bureaucracy is the non-elective government officials by specialisation of functions and follows fixed rules, hierarchy of authority and impartiality (Islam, 2016). The bureaucracy in Bangladesh is inefficient and corrupt because of their involvement in partisan political process and lack of an effective legal framework to control misconducts and corruptions of bureaucrats (Hossain, 2017). The corruption is often termed as rent seeking. Rent seeking is securing private benefits through government activities or offices and the rent of public administration can consist of wage differentials, monetary benefits, nonmonetary job amenities, and bribes through corruptions(Luechinger, Stephan, \& Stutzer, 2008). Bangladesh is a prime ministerial autocracy where the chief executive of the government enjoys mighty and predominant executive power who governs the country through administrative bureaucracy without empowering parliament and establishing political control over public administration (Shelley, 2014). The lust for being in power for a long time, the political leadership of the ruling party in Bangladesh tries to disrupt the democratic process in the country and is involved in a conflicting relationship with other political organization of the country (Landry, 2016). The conflict among political parties and autocracy of head of government has made the political system of the country fragmented and raised the authority and power of the bureaucracy in the country. The ability of bureaucracy to create rent is dependent on the level of authority and stability of political leadership. The fragility in the political leadership of a country transferred the effective power to run the country to the stable part of governance, the bureaucracy. In addition to their managerial power, under a fragmented political regime, the bureaucracy also exercises the politico-administrative authorities because of ineffectual political leadership of the state. Both managerial and policy-making power concentrates in the domain of bureaucrats. It gives them opportunities to be involved in corruption and administrative malpractices taking the advantage of fragmented and feeble political leadership. The bureaucrats run unfriendly and inefficient governance to deprive the citizens from their rights and services for maximizing their rent.

The evidence of corruption in bureaucracy due to concentration of authority in them from fragmented democracy is reported by other researchers in different countries. In Indonesia, collusive corruption, a more decentralized type of corruption in which individual government officials and the private sector collude to rob the government of revenues, increased during weak and fragmented governments (Smith, Obidzinski, Subarudi, \& Suramenggala, 2003). A research study in Japan observed concentration of significant authority among the bureaucrats to regulate the economy and society during fragmented politics in the 1990s and the reputation of flawless anticipatory skills and selfless dedication of bureaucracy under united and stable political regime before 1990s was reduced substantially (Pempel, 1998). The research observed three significant changes in the bureaucracy of Japan during the fragmented political regime in comparison to the previous stable political regime before 1990. First, the bureaucracy was marred by red-tape-laden incompetence and mistrust of people. The credibility of bureaucrats as the source of national success was lost. They became the symbol of gaffe and failure. Second, bureaucracy indulged themselves in corruptions during 1990s. In collaboration with the bureaucracy, the political leaders could involve in corruptions as well. Consequently, many bureaucrats were arrested in 1998 for their corruptions. Third, the bureaucracy gave up their loyalty to political leadership and showed their political ambitions. They came out of their above political character and started to work for their own instead of national interest. Many bureaucrats participated in national elections during 1990s to obtain political offices.

The bureaucrats have the ability to play politicians to maximize their rent seeking, when legislators are weak and separated from administrative power, and this rent seeking has a positive relation to corruption(Luechinger, Stephan, \& Stutzer, 2008). In a democratic system the destructive conflict among 
political parties to reduce the ability of politicians to exercise authorities compared to bureaucrats who have no competitors in administration(Buchanan \& Tullock, 1962; McChesney, 1987) (Buchanan and Tullock, 1962; Persson and Tabellini, 2004; McChesney, 1987). A cross-country analysis of fifty-six countries observed that three factors such as non-competitive political structure, the size of the government and low wages increase the rent seeking in the form of corruption in a country(Montinola \& Jackman, 2002). An earlier study identified the public services in Bangladesh was ridden with corruption of various dimensions and shades like bribery, rent-seeking and misappropriation of funds and the performance of public organizations was adversely affected by excessive lobbying, delays in service provision, irresponsible conduct of officials, bureaucratic intemperance, patronage and clientelism (Zafarullah \& Siddiquee, 2001). The achievement of good governance has been a distant reality in Bangladesh due to poor performance, high incidence of corruption and lack of direction in the public administration (Zafarullah \& Huque, 2001). Institutional disharmony, politicisation and corruption are the barriers to accountability and good governance in Bangladesh and mechanisms of accountability must be strengthened to ensure effective governance (Huque, 2011). The bureaucracy developed alliance with politicians and other powerful groups in the governance system in Bangladesh to ensure their rent seeking behaviour (Huque \& Rahman, 2003). In case of a conflict between bureaucrats and local government functionaries, the control of the government tends to favour the bureaucrats to retain the central control over the local government (Islam, 2016).The public officials do not consider the poor people as an entity deserving respect, do not behave well with citizens and there is no mechanism for ensuring accountability of them to the people of the country (Asaduzzaman, 2009). Hence, a citizen unfriendly rent seeking public administration exists in Bangladesh.

Theoretical Model of Analysis Process: Bangladesh is a fragmented democracy where political parties are always engaged in conflict and avoid constructive competition. It makes the political system weak and administrative power rests in the hands of government officials. The administrative set-up of public administration is such that the authority does not belong to the political component of the government rather authority belongs to the permanent officials and very specifically to administrative bureaucrats in public administration though in a democratic country, the political leaders are responsible for ensuring good governance. The Figure 1 shows the public administration process in Bangladesh. The elected politicians have a responsibility to formulate policy and implementation is the responsibilities of public administration. The components of public administration are administrative bureaucracy, revenue services, technocracy, defence, and internal security services. The administrative bureaucracy controls the decision-making functions at all levels of the government. Technocracy and revenue service do not have direct contact with political leadership, though they provide most of the utility and welfare services to people of the country. Administrative bureaucracy directly controls these two components of administration. Defence, though under the control of bureaucracy, has some autonomy due to their power to create valid threats on the tenure of political leadership in the country like Bangladesh. Judiciary in theory independent in Bangladesh but it is dependent on the administrative bureaucracy for financial reasons and under budgetary control. Police and other internal security forces are formally under the administrative bureaucracy, but, in an informal setup, they operate under direct supervision of political leadership. It is creating power and administrative conflicts in the country between these two components when administrative bureaucracy tries to exercise their formal authorities on forces for internal security. International bureaucracy, composed of donor agencies and UN agencies, works under the direction of administrative bureaucracy in Bangladesh. The legislative body, the parliament of the country, faces negligence in Bangladesh because the representatives of people have almost no formal authority to influence government activities and to ensure the welfare of people.

Successful implementation of policies and management of state is highly dependent on effective cooperation among all parts of government. In existing administrative setup, there is no direct contact among the political leadership with technocracy, revenue service, defence, judiciary and international bureaucracy. All governmental relations and communications go through the administrative bureaucracy where the lowest level bureaucrats have the authority to evaluate the decisions of higher-level technocrats and other officials. Politicians come from within common people and for any wrong, they become accountable to them. The technocrats and support services interact with people to provide services where citizens can evaluate their mistakes. Bureaucrats control the administration, but they remain out of public sight. The common people do not understand the roles of bureaucracy behind all policies and procedures of government. People find politicians, technocrats, and other parts of administration as corrupt, inefficient and ineffective, but do not 
blame bureaucracy in general. Political parties lose power, new party takes over the government office, but the same bureaucracy and administrative system remain operational.

Figure 1: The administrative set-up in Bangladesh for governance of the country.

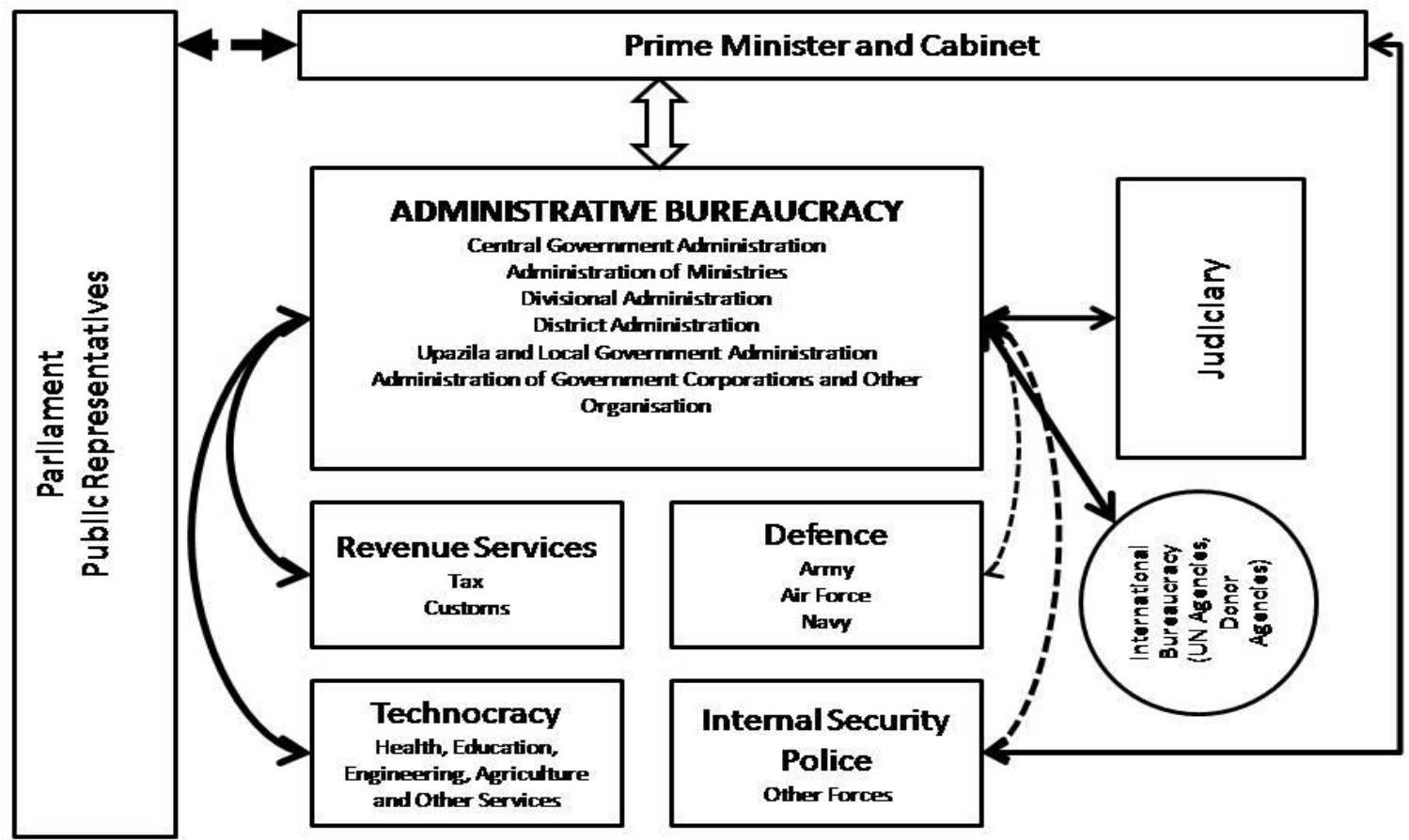

All Powerful Administrative Bureaucracy: The bureaucratic power originates from the present administrative setup and procedures of the government. No other parts of public administration, including political leadership have any authority to make decisions without consent of administrative bureaucracy. Withstanding others, even the head of the government of this country cannot give any official order without proper authorization from many administrative bureaucrats. This procedure gives them the opportunity to play the power game. A number of factors are particular source of power to administrative bureaucracy in this country. First is short tenure and low status of political leadership. Political leadership comes in power for a fixed term through the election process. After starting administration, political officials work with bureaucrats. Soon they realize bureaucracy has all power to spoil their policies. In this situation, the bureaucrats get the opportunity to bargain with the political leadership. The politicians try to avoid risk of failure what may happen if they start a power struggle with strong and united bureaucracy. They accept the dominance of bureaucrats and bureaucracy arranges 'opportunity of corruption' for them. Public representatives, members of parliament (MP), enjoy official status below many bureaucrats. If MPs try to implement their mandate from the people, they face obstacles from the administration. The district administration never gives adequate honour and attention to MPs because of their low status and absence of any administrative authority to make decisions.

Second is the separation of technocracy and other services from political leadership in Bangladesh. The administrative bureaucracy has the responsibility of coordination and monitoring of public services. Technocracy and other services implement policies and programs, but political leaders have no direct decision-making links with these organs of the government. Instructions and orders of political officials reach to the technocrats and support services as orders of bureaucrats. The communications from other service also go to political officials through bureaucrats. The bureaucracy controls information flows and enjoys privileges of blocking or misrepresenting information. Third, political leadership and the technocrats have no authority to take formal decision. Policies are formulated by politicians and implemented by other 
components of the state, but decisions associated with implementation of policies are the domain of administrative bureaucracy. The technocracy, and other services officials need continuous authorisation from bureaucracy in every phase of their functioning. They have the responsibility to implement, but no authority to make decisions about the implementation process. One of the management principles for the organization is that authority and responsibility must coincide for effective functioning. This principle is non-existent in present administrative setups of Bangladesh Government. Politicians and technocrats have responsibilities to public but have no authority to make decisions.

Fourth, despite of recent separation of judiciary from the control of administrative bureaucracy, the judicial system in Bangladesh is highly dependent on the bureaucracy for finance and recruitments. Even the bureaucrats control, the anti-corruption monitoring authority of the country. Bureaucrats deputed from administration runs the administration of anticorruption commission. This system provides unlimited opportunity for bureaucrats to do corruptions and to patronise corruption among politicians, technocrats, and other officials in government. Politicians and other officials understand that they can be involved in corruptions and can save them from punishments if bureaucrats are on their side. This situation makes bureaucracy tremendous powerful as there is none to oppose their functioning. Bureaucrats and others maintain win-win scenario and corruption remains epidemic everywhere in Bangladesh. Finally, there is a nexus between local and international bureaucrats. Bangladesh is highly dependent on foreign financial supports for its development projects. International agencies clearly understand the power centre in the country and always maintain a good relationship with administrators. The international bureaucrats working in multilateral and bilateral agencies support local bureaucracy and try to develop and maintain close relationship with them just to sell their ideas and projects. The bureaucracy in collaboration with the international bureaucrats finalises most of the plans of government. Then they influence the political leaders to accept the plans and force the technocrats and support organizations to implement those. International bureaucrats keep their eyes close to the corruptions and irregularities of local bureaucrats and try to buy support of local bureaucrats through arranging foreign tours, scholarships, luxury cars and other facilities. This sponsorship by international agencies makes bureaucracy more powerful because they can control very important foreign assistances for the country.

Figure 2: Power and accountability of different components in public governance of Bangladesh

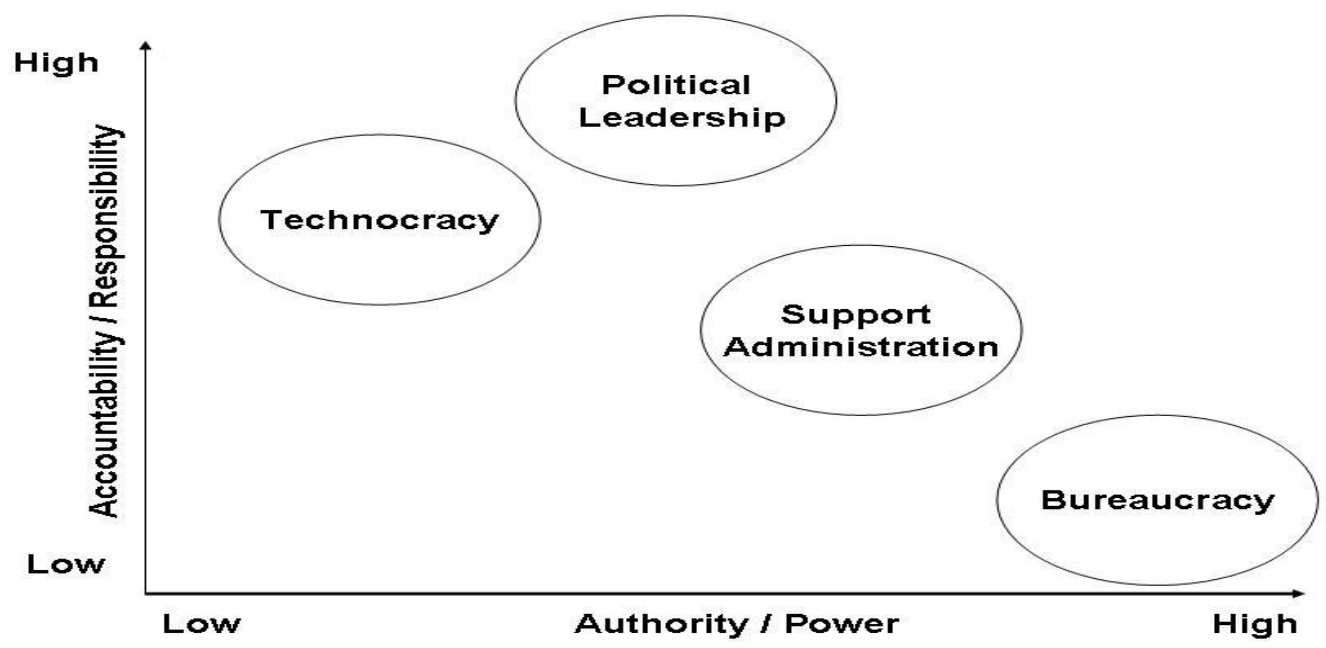

Power versus Accountability in Administration: The Figure 2 is a description of the power versus accountability in public governance of Bangladesh. The bureaucracy enjoys the highest level of power and the lowest level of accountability. The political leadership has less power, but the highest level of accountability. In a fragmented political regime, political leadership cannot even use their limited power effectively. Consequently, the bureaucracy gets an opportunity to use their power without accountability. The 
technocracy, and support services are accountable to the bureaucracy and these two components of governance have limited power. In case of weak political leadership or prime ministerial autocracy, that is very common in Bangladesh, the two components have to work under direction of the bureaucracy. The result is a mighty bureaucracy in the country what is accountable to none but owns the full authority of governance in the country.

\section{Methodology}

This is an empirical cross-sectional study to evaluate the experiences of adult citizens of Bangladesh about the public administration of the country who have experienced service and performance from their interaction with public officials. A field survey with semi-structured questionnaire was administered to collect primary data. The survey used non-probability purposive sampling technique for data collection. The survey was planned to evaluate seven components of public administration - administrative bureaucracy, revenue collection, police, defence, engineering services, medical service, and other services. The questionnaire had three components. First part was to collect demographic data of respondents. Second part is to obtain data on the definition and scale of rent seeking evaluated by the respondents. The third section gathered data on the experiences of respondents about rent seeking and the unfriendliness of the administration as a composite measure and the impact of these on them.

Data Description: The data are collected from 2394 respondents of ages above 18 years in 41 districts of Bangladesh. Among the respondents 1781 (74.4\%) were men and 614 (25.6\%) were women. This survey has analysed opinion of people on the nature and extent of rent seeking, corruption, and unfriendliness among government officials and impact of those on the livelihood of people. Hence, the ineffectiveness of different wings of public administration has been measured in terms of the level of corruption in them perceived by the citizens of the country. The level of corruption among each of seven components was measured on a categorical scale of five levels. These are highest (10.0), higher (7.5), average (5.0), below average (2.5) and non-existent (0). The respondents are grouped in five hierarchical percentile income groups. The levels of education of the respondents are classified into six groups - primary, below secondary, secondary, and higher secondary, graduate, and post-graduate. The respondents were divided into five income percentile groups based of reported household income of the respondents.

Analytical Methods: The average level of rent seeking or corruption for each seven wings of public administration, reported by respondents, is calculated from the data as the arithmetic mean. The perception of corruption among the administration is also analysed according to income and education levels of the citizens. The mean corruption levels of each wing of the administration by income and education levels of the citizens are calculated. This is done to understand how various socioeconomic groups perceived corruption or rent-seeking among seven wings of the administration. The differences in perception of corruptions among different wings of administration for income and education levels of the respondents are analysed by using Two-Way ANOVA. The null hypotheses for income levels of the citizens for the Two-Way ANOVA are the following.

$\mathrm{H}_{0}$ : There is no difference in the means of different income levels of the citizens

$\mathrm{H}_{0}$ : There is no difference in means of different wings of the administration

$\mathrm{H}_{0}$ : There is no interaction between income levels of citizens and wings of the administration.

Similarly, the null hypotheses for education levels of the citizens for the Two-Way ANOVA are the following.

$\mathrm{H}_{0}$ : There is no difference in the means of different education levels of the citizens

$\mathrm{H}_{0}$ : There is no difference in means of different wings of the administration

$\mathrm{H}_{0}$ : There is no interaction between the education levels of citizens and wings of the administration.

The types of corruptions or rent seeking and consequences of rent seeking are calculated as frequency of comments by the respondents for different criteria and variables. The selected variable for analysis of types of rent seeking are bribes, nepotism and favouritism, use power to mischief common people, negligence to official duties and responsibilities. The impact of the rent seeking on the citizens is analysed from their 
opinion to an open-ended question and the most frequent impacts are discussed in this paper. This analysis explores the ineffectiveness of the governance of the country.

\section{Findings}

The respondents participated in the survey are classified in five income groups and six educational groups for analysis of the experiences of people across social structure. This survey defined rent seeking as unethical activities help people in public offices to earn wealth for own or for some close ones that they should not get under existing rules and regulations. About 92 percent of the respondents agreed to this definition and they identified corruption as primary form of rent seeking in the public services.

Levels of Rent Seeking in Administration: This paper evaluated the level of rent seeking or corruption among the components of public administration on a scale between 0 and 10 . According to respondents, top three corrupt components of the administration are police (8.24), revenue service (8.01), and administrative bureaucracy (7.48). Lowest level of corruption exists among the defence (3.27). The Figure 3 shows the level of corruption in different wings of governance of the country perceived by citizens participated in the survey.

Figure 3: Level of corruption among different wings of governance in Bangladesh.

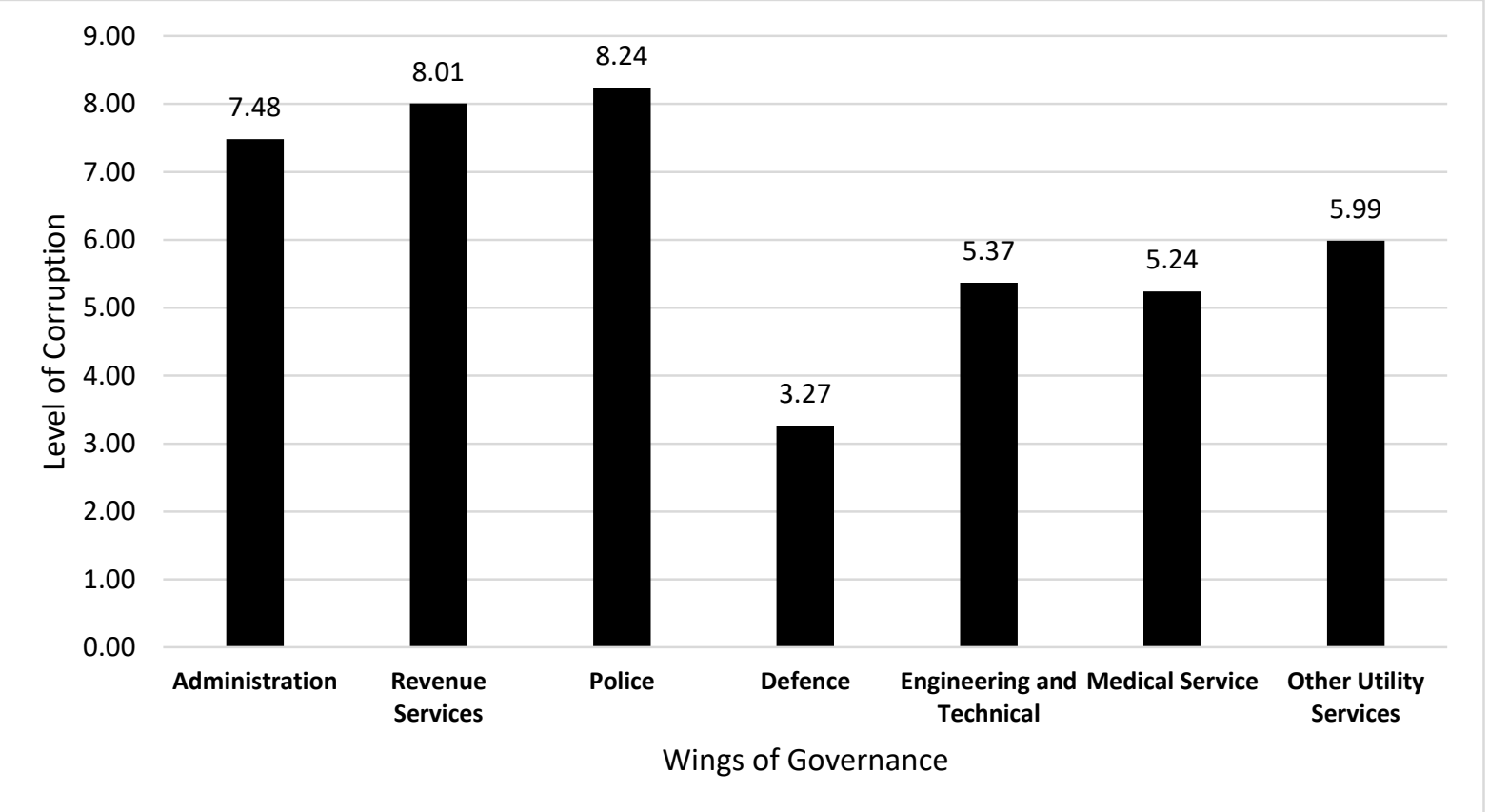

Perceived corruption and Income Level of Citizens: The Table 1 shows the level of rent seeking in the form of corruption measured by the respondents of the survey. The perception of corruption among the citizens by income levels are not very different for individual wings of public governance. Revenue services, police and administration have higher levels of corruption and defence has lowest level according to the respondent citizens. The Table 2 presents the Two-Way ANOVA statistics for analysis of differences in perception of corruptions among wings of governance for each income level.

Table 1: Level of rent seeking in the form of corruption among professional groups in public administration perceived by citizens of different level of income

\begin{tabular}{|c|c|c|c|c|c|c|c|}
\hline \multirow{2}{*}{$\begin{array}{l}\text { Income } \\
\text { Group }\end{array}$} & \multicolumn{7}{|c|}{ Wings of Governance } \\
\hline & $\begin{array}{l}\text { Administrative } \\
\text { Bureaucracy }\end{array}$ & $\begin{array}{l}\text { Revenue } \\
\text { Collection }\end{array}$ & Police & Defence & $\begin{array}{l}\text { Engineering } \\
\text { Services }\end{array}$ & $\begin{array}{l}\text { Medical } \\
\text { Services }\end{array}$ & $\begin{array}{l}\text { Other } \\
\text { Services }\end{array}$ \\
\hline $\begin{array}{l}\text { Top } 20 \\
\text { Percent }\end{array}$ & 7.57 & 8.30 & 8.49 & 3.32 & 5.37 & 5.14 & 6.20 \\
\hline
\end{tabular}




$\begin{array}{llllllll}\text { Second 20 } & 7.60 & 7.83 & 8.33 & 3.33 & 5.35 & 5.62 & 6.11 \\ \begin{array}{l}\text { Percent } \\ \text { Third 20 }\end{array} & 7.55 & 8.09 & 8.33 & 3.19 & 5.55 & 5.14 & 5.87 \\ \begin{array}{l}\text { Percent } \\ \text { Fourth } 20\end{array} & 7.53 & 8.30 & 8.19 & 3.37 & 5.46 & 5.20 & 6.13 \\ \begin{array}{l}\text { Percent } \\ \text { Bottom } 20\end{array} & 7.16 & 7.51 & 7.87 & 3.13 & 5.12 & 5.10 & 5.61 \\ \text { Percent } & & & & & \end{array}$

There are no significant effects of the wings of bureaucracy and levels of income. It can be concluded that the perception of corruptions among each wing of governance and among each level of income is not different. However, there is statistically significant effect of wings of governance and levels of income. It indicates that the corruption level differs among wings of governance as perceived by citizens of different income levels

Table 2: Level of rent seeking in the form of corruption for wings of governance and level of incomes The Two-Way ANOVA analysis

\begin{tabular}{|c|c|c|c|c|c|}
\hline Source & $\begin{array}{l}\text { Type III Sum } \\
\text { Squares }\end{array}$ & $\begin{array}{r}\begin{array}{c}\text { of Degree } \\
\text { freedom }\end{array} \\
\end{array}$ & of Mean Square & $\mathbf{F}$ & Sig. \\
\hline Corrected Model & $46919.287^{a}$ & 34 & 1379.979 & 161.259 & .000 \\
\hline Intercept & 650219.270 & 1 & 650219.270 & 75982.005 & .000 \\
\hline Wings of Bureaucracy & 46260.127 & 6 & 7710.021 & 900.962 & .000 \\
\hline Level of Income & 392.472 & 4 & 98.118 & 11.466 & .000 \\
\hline Wings * Income Level & 266.688 & 24 & 11.112 & 1.299 & .149 \\
\hline Error & 143167.693 & 16730 & 8.558 & & \\
\hline Total & 840306.250 & 16765 & & & \\
\hline Corrected Total & 190086.980 & 16764 & & & \\
\hline
\end{tabular}

a. R Squared $=.247$ (Adjusted R Squared $=.245$ )

Perceived corruption and Education Level of Citizens: The perception of corruption seems to be influenced by the level of education of citizens. The Table 3 presents the level of corruption perceived by citizens at different level of education. The citizens with low level education perceived relatively low level of corruption. However, people of all levels of education have identified revenue services, police, and administration as more corrupt wings of governance. The Table 4 presents the Two-Way ANOVA statistics for analysis of differences in perception of corruptions among wings of governance for each education level. There is no statistically significant effect of corruption perception for education level and wings of governance. The respondents perceived the corruption level similarly and there is no statistically significant difference for interaction between level of education and wings of governance.

Table 3: Level of rent seeking in the form of corruption among professional groups in public administration perceived by citizens of different level of education

\begin{tabular}{|c|c|c|c|c|c|c|c|}
\hline \multirow{2}{*}{$\begin{array}{l}\text { Level of } \\
\text { Education }\end{array}$} & \multicolumn{7}{|c|}{ Wings of Governance } \\
\hline & $\begin{array}{l}\text { Administrative } \\
\text { Bureaucracy }\end{array}$ & $\begin{array}{l}\text { Revenue } \\
\text { Collection }\end{array}$ & Police & Defence & $\begin{array}{l}\text { Engineering } \\
\text { Services }\end{array}$ & $\begin{array}{l}\text { Medical } \\
\text { Services }\end{array}$ & $\begin{array}{l}\text { Other } \\
\text { Services }\end{array}$ \\
\hline $\begin{array}{l}\text { Primary } \\
\text { Education }\end{array}$ & 6.02 & 6.27 & 6.90 & 3.13 & 4.16 & 4.22 & 5.21 \\
\hline $\begin{array}{l}\text { Secondary } \\
\text { Level }\end{array}$ & 6.94 & 7.22 & 8.28 & 2.58 & 4.81 & 5.06 & 5.28 \\
\hline $\begin{array}{l}\text { Secondary } \\
\text { Examination }\end{array}$ & 7.36 & 7.62 & 7.77 & 3.02 & 5.01 & 4.77 & 5.95 \\
\hline $\begin{array}{l}\text { Higher } \\
\text { Secondary }\end{array}$ & 7.36 & 7.71 & 7.90 & 2.98 & 5.13 & 4.90 & 6.01 \\
\hline
\end{tabular}


Examination

$\begin{array}{llllllll}\text { Graduation } & 7.63 & 8.24 & 8.43 & 3.22 & 5.34 & 5.41 & 5.99 \\ \begin{array}{l}\text { Post- } \\ \text { Graduation }\end{array} & 7.63 & 8.29 & 8.49 & 3.68 & 5.87 & 5.50 & 6.16\end{array}$

Characteristics of Rent Seeking: Four common forms of corruptions are bribes (83.5\%), nepotism, and favouritism (66.8\%), use of official power to mischief common people $(65.1 \%)$, and negligence to official duties and responsibilities (63.1\%). The Table 5 shows details of corruption characteristics of all professional groups. The respondents have identified administrative bureaucracy and revenue collection group are highly involved in these activities. People considered defence as less corrupt. Both revenue and administrative officials used to mischief common people most by using their state authorities. Police follows them at very close range to mischief common people of the country. In overall, the first three rent-seeking professions are revenue collection, administrative bureaucracy, and police.

Figure 4: Level of rent seeking in the form of corruption for wings of governance and level of education - The Two-Way ANOVA analysis

\begin{tabular}{llllll}
\hline \multirow{2}{*}{ Source } & $\begin{array}{l}\text { Type III } \\
\text { Squares }\end{array}$ & $\begin{array}{c}\text { of Degree of Mean } \\
\text { freedom }\end{array}$ & Square & F & \multirow{2}{*}{ Sig. } \\
\hline Corrected Model & $48263.904^{\mathrm{a}}$ & 41 & 1177.168 & 138.805 & .000 \\
Intercept & 271110.832 & 1 & 271110.832 & 31967.904 & .000 \\
Wings of Governance & 19746.255 & 6 & 3291.043 & 388.062 & .000 \\
Levels of Education & 1596.413 & 5 & 319.283 & 37.648 & .000 \\
Wings * Level of education & 407.364 & 30 & 13.579 & 1.601 & .020 \\
Error & 141823.076 & 16723 & 8.481 & & \\
Total & 840306.250 & 16765 & & & \\
Corrected Total & 190086.980 & 16764 & & & \\
\hline
\end{tabular}

a. $\mathrm{R}$ Squared $=0.254$ (Adjusted R Squared $=.252$ )

Table 5: Characteristics of corruption among different professional groups in public administration

\begin{tabular}{|c|c|c|c|c|c|}
\hline \multirow[b]{2}{*}{$\begin{array}{l}\text { Professional } \\
\text { Groups }\end{array}$} & \multicolumn{5}{|c|}{ Types of Corruptions in Percentage } \\
\hline & Bribes & $\begin{array}{l}\text { Nepotism } \\
\text { and } \\
\text { favouritism }\end{array}$ & $\begin{array}{l}\text { Use power to } \\
\text { mischief } \\
\text { common people }\end{array}$ & $\begin{array}{c}\text { Negligence to official } \\
\text { duties and } \\
\text { responsibilities }\end{array}$ & $\begin{array}{l}\text { Geometric } \\
\text { Mean }\end{array}$ \\
\hline $\begin{array}{l}\text { Administrative } \\
\text { Bureaucracy }\end{array}$ & 82.6 & 66.2 & 64.6 & 62.4 & 68.5 \\
\hline $\begin{array}{l}\text { Revenue } \\
\text { Collection }\end{array}$ & 82.7 & 66.4 & 64.6 & 62.7 & 68.7 \\
\hline Police Services & 82.0 & 65.8 & 64.1 & 62.2 & 68.1 \\
\hline $\begin{array}{l}\text { Defence } \\
\text { Services }\end{array}$ & 65.8 & 52.9 & 51.3 & 50.2 & 54.7 \\
\hline $\begin{array}{l}\text { Engineering } \\
\text { Services }\end{array}$ & 78.8 & 63.6 & 61.2 & 60.0 & 65.5 \\
\hline $\begin{array}{l}\text { Medical } \\
\text { Services }\end{array}$ & 78.3 & 63.0 & 60.8 & 59.6 & 65.0 \\
\hline $\begin{array}{l}\text { Other } \\
\text { Services }\end{array}$ & 82.2 & 65.8 & 64.2 & 62.0 & 68.0 \\
\hline All Groups & 83.5 & 66.8 & 65.1 & 63.1 & 69.2 \\
\hline
\end{tabular}


Impact of Rent Seeking: Respondents reported two types of impact of rent seeking. First, they explained the impact on daily life of them. 59.7 percent of respondents had to pay bribe money for services from public officials, 57.6 percent people faced long delays to complete their desired work, and 24.2 percent of them could not get necessary services from the administration. About 63 percent of the respondents faced financial stress due to rent seeking behaviour of the public administration. Those who had to meet financial and other demands of the public administration for necessary public service arranged necessary resources in combination of various modes. About 77 percent used money that was allocated for other purposes, 79 percent used up their saving, 74 percent-borrowed money from others and 93 percent had to sell some assets. A large majority, 94.2 percent felt, they could improve their financial conditions if there were no rent seeking by public administration. Analysis of the estimates of respondents shows that the average increase in income of households may be around \$61.2 per month in the absence of corruption among public administration.

The second impact of rent seeking is on national economic growth. 71.5 percent people feel the growth rate is slow in Bangladesh. They pointed to a number of factors as barriers to faster economic growth and Table3 presents the opinion of respondents. Among the barriers, the most important cause was corruption and nepotism (88.8\%). The next two issues related to political leadership. 74.4 percent people identified corruption in bureaucracy as an impediment to development. According to the respondents of the survey political instability and foreign aid, public administration creates all other barriers to the development process of Bangladesh.

Table 6: Opinion of respondents about impediments to development in Bangladesh

\begin{tabular}{ll}
\hline Impediments to Development & Percent \\
\hline Corruption and nepotism in public administration & 88.8 \\
Political instability & 84.8 \\
Ineffective political leadership & 84.0 \\
Law and order situation & 80.6 \\
Corruption in administrative bureaucracy & 74.4 \\
Inefficiency of government officials & 73.2 \\
Shortage of domestic resources & 43.7 \\
Reduction of foreign aid & 33.5 \\
\hline
\end{tabular}

Analysis: The fragility of democracy in Bangladesh has made political leadership weak and transferred the effective authority of governing the country to public administration. In the public administration, the administrative bureaucracy is most powerful. With a permanent tenured job and accountability to none, the administrative bureaucracy becomes highly rent seeking component of administration. In cooperation with administrative bureaucracy, all other components of the state, including political leadership may exercise rent seeking behaviour. The citizens observed very high level of bribes (82.6\%) among administrative officials and very high level of nepotism and favouritism (66.2\%), use power to mischief common people $(64.6 \%)$ and negligence to official duties and responsibilities (62.4\%). The revenue officials discharge duties related to the monetary benefits of people. In unison with business and social opportunists, revenue official may involve themselves in rent seeking. Police have the coercive power to exploit common people. Other services, except administration, have opportunities of corruptions. The administrative bureaucracy does not have a direct opportunity to be involved in corruption and they are involved in monitoring and controlling duties of other services in the country. Rent seeking by the administrative bureaucracy is possible only through exercising their discretionary power to control functions of other services in public administration. Unfortunately, this section of the public administration is highly corrupt and the result is unabated rent seeking by all components of public governance as discussed in the literature review that the country lacks legal framework to control misconducts of bureaucrats (Hossain, 2017).

Previous discussion pointed to the fact that the administrative bureaucracy holds the ultimate power in the public governance of Bangladesh. During a fragmented regime or weak government, the bureaucrats get the opportunity to run the country. In result, the political leadership fails to meet the demands of common people and soon become unpopular. The fragmented political regime reduces the accountability of the bureaucrats 
further. Corrupt, inefficient, and insensitive bureaucrats in the fragmented political regime cause inefficiency in the society and common person's loss welfare. Therefore, the result is bad governance in the fragmented political regime in Bangladesh that slows down the pace of development in the country. The public administration in Bangladesh needs effective reforms for reducing public suffering and public economic losses. The objective of this reform process must be to reduce and, if possible, to eliminate the power of administrative bureaucracy as it appears to be the root of all rent seeking because the administrative bureaucracy enjoys the opportunities developed alliance with politicians and other powerful groups in the governance system to ensure their rent seeking behaviour (Zafarullah \& Huque, 2001).

Elimination of the parallel structures in the government is essential. The ministries and divisions can be converted into corporate structure where administration and technocracy can work together. There must not be any horizontal movement of administrative officials from one ministry to another ministry. Limiting the movement of bureaucrats and technocrats within one ministry the government will get specialized functional administration like private sector business firms. Political officials must be the executive head of the ministries and all departmental heads of the ministry must have a right to report directly to him/her. This system may increase effectiveness and efficiency of ministries by bringing in dynamism, flexibility, and accountability. It will reduce the dominance of the bureaucracy in the government and eliminate professional conflict among different cadres of the government. Fragmented and weak government has become common in Bangladesh. The result is dissatisfaction of common people to political leadership because bureaucrats do mistakes and responsibilities are borne by political leaders. The political component of government cannot establish good governance without changing the administrative setup during this situation. The present colonial administrative structure is unable to support a democratic state mechanism because the bureaucracy holds all administrative power. Only the elimination of the mighty bureaucracy that is the root of bad governance in the country may help to establish pro-peoples' governance where skill, knowledge, and efficiency will be the prime mover of all administrative activities.

\section{Conclusion}

The public governance in Bangladesh does not meet the characteristics of good governance. The governance is an exclusive domain of the administrative bureaucracy and out of the reach of common people and political leadership. It is neither participatory nor responsive. This bureaucracy is accountable to none; transparency is absent; and the rule of law is bureaucrats' interest. It cannot ensure equity and inclusiveness because it only ensures benefits for bureaucrats. No-one considers the governance in Bangladesh is efficient and effective. In the previous section of this paper, it was explained that the administrative bureaucracy in fact holds the administrative power in Bangladesh and 73.4 percent respondents identified government officials as inefficient. Political leadership cannot be effective without efficient bureaucrats and other officials. Without honest and sincere cooperation of public administration, politicians cannot ensure good law and order situation or collect resources from internal sources for development of the country. It is significant to notice that 74.4 percent people considered corruption among administrative bureaucrats is a barrier to economic growth of the country. Hence, the country has ineffective governance because of concentration of authority in administrative bureaucracy.

\section{References}

Alam, H. (2011). Good governance in Bangladesh: The role of the civil services. Retrieved February 02, 2018, from FORUM: http://archive.thedailystar.net/forum/2011/August/index.htm

Asaduzzaman, M. (2009). Development Role of the Local Governance Institutions in Bangladesh: Emperical Overview. Nepalese Journal of Public Policy and Governance, xxiv(1), 96-111.

Buchanan, J. M.\& Tullock, G. (1962). The Calculus of Consent: Logical Foundations of Constitutional Democracy. Ann Arbor: University of Michigan Press.

Doullah, S. U. (2016). Policicization of Bureaucracy and Good Governance: Bangladesh Perspective. International Research Journal of Social Sciences, 5(2), 28-32.

Ferdous, J. (2016). Bureaucracy in Bangladesh: Past, Present Experiences and Future Expectations. Public Policy and Administrative Research, 6(4), 1-10. 
Hossain, M. A. (2017). Bureaucratic System in Bangladesh. Review of Public Administration and Management, 5(2), 1000214.

Huque, A. S. (2011). Accountability and governance: strengthening extra-bureaucratic mechanisms in Bangladesh. International Journal of Productivity and Performance Management, 60(1), 59-74.

Huque, A. S. \& Rahman, M. T. (2003). From Domination to Alliance: Shifting Strategies and Accumulation of Power by the Bureaucracy in Bangladesh. Public Organization Review, 3(4), 403-418.

Islam, R. (2016). Bureaucracy and Administrative Culture in Bangladesh. In A. Farazmand, Global Encyclopedia of Public Administration, Public Policy, and Governance. Cham: Springer.

Landry, D. (2016). The Downfall of Democracy in Bangladesh. Retrieved from The Diplomat: https://thediplomat.com/2016/07/the-downfall-of-democracy-in-bangladesh/

Luechinger, S., Stephan, M. \& Stutzer, A. (2008). Bureaucratic Rents and Life Satisfaction. Journal of Law, Economics, and Organization, 24(2), 476-488.

McChesney, F. S. (1987). Rent Extraction and Rent Creation in the Economic Theory of Regulation. The Journal of Legal Studies, 16(1), 101-118.

Mollah, M. A. (2011). Growth and Development of Civil Services and Bureaucracy in Bangladesh: An Overview. South Asian Survey, 18(1), 137-156.

Montinola, G. R. \& Jackman, R. W. (2002, January). Sources of Corruption: A Cross-Country Study. British Journal of Political Science, 32(1), 147-170.

Pempel, T. J. (1998). Regime Shift: Comparative Dynamics of the Japanese Political Economy. Ithaca: Cornell University Press.

Persson, T.\& Tabellini, G. (2004). Constitutions and Economic Policy. Journal of Economic Perspectives, 18(1), 75-98.

Rashid, A. K. (2014). The role of the bureaucracy in policymaking in Bangladesh. Asia Pacific Journal of Public Administration, 36(2), 150-161.

Shelley, M. R. (2014). Prime Ministerial autocracy? Retrieved from The Daily Star: http://www.thedailystar.net/prime-ministerial-autocracy-14563

Smith, J., Obidzinski, K., Subarudi, L. \& Suramenggala, I. (2003). Illegal logging, collusive corruption and fragmented governments in Kalimantan, Indonesia. International Forestry Review, 5(3), 293-302.

UNESCO. (2018). EDUCATION. Retrieved from United Nations Educational, Scientific and Cultural Organization: http://www.unesco.org/new/en/education/themes/strengthening-educationsystems/quality-framework/technical-notes/concept-of-governance/

Zafarullah, H. \& Huque, A. S. (2001). Public Management for Good Governance: Reforms, Regimes, and Reality in Bangladesh. International Journal of Public Administration, 24(12), 1379-1403.

Zafarullah, H. \& Siddiquee, N. A. (2001). Dissecting Public Sector Corruption in Bangladesh: Issues and Problems of Control. Public Organization Review, 1(4), 465-486. 